\title{
The effect of corporate disclosure policy on risk assessment and market value: Evidence from Tehran Stock Exchange
}

\author{
Raziyeh Masalegooha $^{a}$ and Mohsen Hamidian ${ }^{b^{*}}$
}

${ }^{a}$ Department of Management and Accounting, South Tehran Branch, Islamic Azad University, Tehran, Iran ${ }^{b}$ Faculty member, Department of Management and Accounting, South Tehran Branch, Islamic Azad University, Tehran, Iran

\begin{tabular}{|c|c|}
\hline CHRON I C L E & A B S T R A T T \\
\hline $\begin{array}{l}\text { Article history: } \\
\text { Received January 2, } 2015 \\
\text { Received in revised format } 6 \\
\text { February } 2015 \\
\text { Accepted } 5 \text { March } 2015 \\
\text { Available online } \\
\text { March } 122015 \\
\text { Keywords: }\end{array}$ & $\begin{array}{l}\text { This paper investigates the role of corporate disclosure policy on risk assessment and market } \\
\text { value on selected firms from Tehran Stock Exchange over the period 2004-2012. The study } \\
\text { considers four risk namely; business risk, cash flow risk, financial risk and systemic risk. Using } \\
\text { regression analysis with panel data under fixed effect, the study shows that there was a } \\
\text { meaningful relationship between two risks, business risk and systematic risk, and market value } \\
\text { before and after corporate disclosure. In other words, after corporate disclosure, the } \\
\text { relationship between risk and market value becomes stronger. }\end{array}$ \\
\hline
\end{tabular}

Tehran Stock Exchange

Corporate disclosure

Risk assessment

\section{Introduction}

One of the most important issues in investment plans is to detect any kind of risk associated with firms and there are literally many studies to determine the risk factors (Roe, 1996; Scott, 1997; Steger \& Amann, 2008; Bertomeu \& Cheynel, 2014). Corporate disclosure policy plays essential role for keeping investors inform about any possible risk in firms. Abraham and Shrives (2014) developed a model for evaluating the quality of risk disclosures and used it for four firms in the food production and processing sector. In their survey, adopted a normative technique to disclosure by recommending a way of improving risk reporting disclosures, they provided guidance for current and future company managers and determined certain problems with existing risk disclosures. They recommended that company managers prefer providing disclosures that were symbolic rather than substantive. They argued that institutional factors and proprietary costs contribute towards and could describe this behavior. 
Anandarajan and Hasan (2010) examined how differences in levels of mandated disclosures, source of accounting standards, and legal systems could moderate the usefulness of earnings to investors. They reported that mandated disclosure and source of accounting standard were positively related to earnings usefulness. Moreover, MENA countries with French civil law and systems had lower value relevance relative to countries in this study with English and related legal codes. Chung et al. (2010) investigated the relationship between corporate governance and stock market liquidity and reported that firms with better corporate governance had narrower spreads, higher market quality index, smaller price impact of trades, and lower probability of information-based trading. Moreover, they explained that changes in their liquidity measures were significantly associated with changes in the governance index over time. These results implied that firms could reduce information-based trading and improve stock market liquidity by adopting corporate governance standards that mitigate informational asymmetries.

Ezat and El-Masry (2008) investigated the impact of corporate governance on the timeliness of corporate internet reporting by Egyptian listed companies. Ferguson et al. (2002) examined the effect of international capital market pressures on the voluntary disclosure of three kinds of information in the annual reports of former wholly state-owned People's Republic of China (PRC) enterprises, listed on the Stock Exchange of Hong Kong (SEHK). They reported that PRC H-Share firms disclosed substantially more strategic and financial information than other SEHK firms. Gelb and Zarowin (2002) investigated the association between voluntary corporate disclosure and the informativeness of stock prices. They measured corporate disclosure using the AIMR-FAF annual corporate disclosure ratings. They reported that greater disclosure was associated with stock prices that were more informative about future earnings.

Hasan et al. (2008) studied the effectiveness of changes in the regulatory environment on the quality of compliance to mandatory disclosure requirements in Bangladesh. They reported that lack of a firm's profitability did not influence on the quality of its compliance, and the performance of domestic firms were at par with foreign affiliated firms as far as the quality of the compliance was concerned. Li (2010) studied how firms' voluntary disclosure decisions were influenced by product market competition. The study indicated that competition from potential entrants increased disclosure quantity while competition from existing rivals decreased disclosure quantity. Li et al. (2012) investigated the hypotheses that liquidity could improve corporate governance, and better governance enhances valuation of Russian firms. They reported a positive causal relationship between measures of liquidity and corporate governance. Moreover, they reported the strong positive impact of corporate governance on valuation. Their findings were economically significant. For instance, they reported that a $10 \%$ decrease in the proportion of zero return days implied a $0.34 \%$ increase in transparency and disclosure, which in turn could lead to a 9.6\% increase in firm valuation. $\mathrm{Ng}$ (2011) studied whether information quality could influence on the cost of equity capital through liquidity risk. The study reported that higher information quality was associated with lower liquidity risk and that the reduction in cost of capital due to this association was economically substantial. They study also indicated that the negative association between information quality and liquidity risk was stronger in times of large shocks to market liquidity.

\section{The proposed study}

This paper investigates the role of corporate disclosure policy on risk assessment and market value on selected firms from Tehran Stock Exchange over the period 2004-2012. The study considers four risk namely; business risk, cash flow risk, financial risk and systemic risk. The study uses a model developed by Abraham and Shrives (2014) as follows,

$\mathrm{FV}_{\mathrm{jt}}=\beta_{0}+\beta_{1} \mathrm{BR}_{\mathrm{jt}}+\beta_{2} \mathrm{CFR}_{\mathrm{jt}}+\beta_{3} \mathrm{FR}_{\mathrm{jt}}+\beta_{4} \mathrm{SR}_{\mathrm{jt}}+\beta_{5} \mathrm{D}_{1} \times \mathrm{BR}_{\mathrm{jt}}+\beta_{6} \mathrm{D}_{1} \times \mathrm{CFR}_{\mathrm{jt}}+\beta_{7} \mathrm{D}_{1} \times \mathrm{FR}_{\mathrm{jt}}+\beta_{8}$

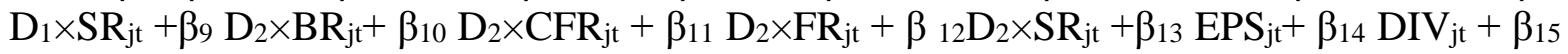

$\mathrm{SIZE}_{\mathrm{jt}}+\varepsilon_{\mathrm{jt}}$ 
where Financial value (FV) is a function of business risk (BR), cash flow risk (CFR) (Francis et al., 2000), financial risk (FR) (Pastor \& Stambaugh, 2001), systematic risk (SR), earnings per share (EPS), dividend per share (DIV) and firm size (SIZE). In addition, the study uses $\mathrm{D}_{1}$ and $\mathrm{D}_{2}$ as dummy variables as follows,

$\mathrm{D}_{1}=1$ for data over the period 2004-2008, five years before corporate disclosure police, and zero, otherwise. $\mathrm{D}_{2}=1$ for data over the period 2009-2012, five years after corporate disclosure police, and zero, otherwise.

In our survey, $\beta_{0}, \ldots, \beta_{15}$ are estimated coefficients and $\varepsilon$ represents residuals. In this survey, business risk $(\mathrm{BR})$ is measured as follows,

$$
B R=\frac{Q(P-V)}{Q(P-V)-F},
$$

where $Q, P, V$ and $F$ represent sales number, price, variable and fixed cost, respectively. Cash flow risk (CFR) is calculated by measuring standard deviation of cash flow. Financial risk (FR) is also calculated as follows,

$$
F R=\frac{Q(P-V)}{Q(P-V)-F-I},
$$

where $I$ represents interest paid. In our survey, $(\beta)$, represents systematic risk, which is measured as follows,

$$
\beta=\frac{\operatorname{cov}\left(R_{i}-R_{M}\right)}{\operatorname{var}\left(R_{M}\right)},
$$

where $R_{i}$ and $R_{M}$ represent firm's return and market return, respectively. In our survey, SIZE is calculated by taking natural logarithm of total assets. The study collects the information from official statements of 105 firms from Tehran Stock Exchange. Table 1 demonstrates the summary of some basic statistics. In addition, the study uses Im, Pesaran and Shin (Pesaran \& Shin, 1998) test to verify whether the data were stationary or not. Table 2 demonstrates the results.

\begin{tabular}{|c|c|c|c|c|c|c|c|}
\hline Variable & Mean & Median & Standard & Skewness & Kurtosis & Min & Max \\
\hline FV & 18.4785 & 18.5564 & 1.1521 & -0.8901 & 1.1118 & 13.1323 & 20.1375 \\
\hline BR & 2.9709 & 2.968 & 0.1394 & 0.0695 & -0.8168 & 2.7083 & 3.2322 \\
\hline CFR & -0.1627 & -0.1185 & 1.7158 & -0.0313 & -1.1349 & -3.2908 & 2.8838 \\
\hline FR & 1.9842 & 1.9823 & 0.0931 & 0.0695 & -0.8168 & 1.8088 & 2.1587 \\
\hline SR & 0.1856 & 0.1352 & 1.9569 & 0.0313 & -1.1349 & -3.2892 & 3.7534 \\
\hline EPS & 418.8735 & 399.663 & 119.21 & 0.5921 & -1.4023 & 258.771 & 707.232 \\
\hline DIV & 0.5564 & 0.5551 & 0.1385 & 0.035 & -1.2035 & 0.3131 & 0.817 \\
\hline Size & 16.0329 & 16.1005 & 0.9996 & -0.8901 & 1.1118 & 11.3942 & 17.4723 \\
\hline
\end{tabular}

Table 1

The summary of some basic statistics

Table 2

The summary of IPS test

\begin{tabular}{ccccccccc}
\hline Variable & Firm Value & BR & CFR & FR & SR & EPS & DIV & Size \\
\hline W-stat & 10.887 & -11.543 & 7.231 & -18.231 & 13.432 & 8.193 & -16.832 & 0.1211 \\
p-value & 0.0028 & 0.002 & 0.031 & 0.0052 & 0.001 & 0.026 & 0.00081 & 0.00191 \\
\hline
\end{tabular}

As we can observe from the results of Table 2, all statistics are stationary and we can use regression technique to verify the hypotheses of the survey. In addition, the implementation of Chaw test indicates that we should use Panel data to do the regression test $(\mathrm{F}$-value $=18.765 \mathrm{P}$-value $=0.012)$. Moreover, the implementation of Hausman yields a Chi-Square value of 38.909 with P-value $=0.0082$, which means we should use fixed effect. Kolmogorov-Smirnov test yields $\mathrm{z}=1.6565$ with P-value $=0.1092$, which means the data were normally distributed. Finally, Durbin-Watson value is equal to 1.822, which is within the acceptable limit and we can conclude that there were no autocorrelation among residuals. 
In order to understand whether there were any correlation among independent variables, we examine variance inflation and Table 3 shows the results of our survey.

Table 3

The summary of inflation of variance

\begin{tabular}{cccccccc}
\hline Variable & BR & CFR & FR & SR & EPS & DIV & SIZE \\
\hline Tolerance & 0.5675 & 0.3456 & 0.5065 & 0.341 & 0.3083 & 0.3765 & 0.5324 \\
Inflation & 1.762 & 2.893 & 1.974 & 2.932 & 2.243 & 2.656 & 1.878 \\
\hline
\end{tabular}

According to the results of Table 3, we understand that there were no strong correlation among various components of the survey. Table 4 demonstrates the results of correlations among different pairs of variables.

Table 4

The summary of correlation among various pairs of independent variables

\begin{tabular}{ccccccccc}
\hline Variable & Firm Value & BR & CFR & FR & SR & EPS & DIV & Size \\
\hline Firm Value & 1 & & & & & & & \\
BR & -0.4287 & 1 & & & & & & \\
CFR & -0.1958 & 0.2335 & 1 & & & & & \\
FR & -0.1346 & 0.0424 & 0.0238 & 1 & & & & \\
SR & -0.0061 & 0.0048 & 0.0016 & 0.0238 & 1 & & & \\
EPS & 0.116 & 0.022 & 0.0881 & 0.0934 & 0.0029 & 1 & & \\
DIV & 0.0948 & 0.0406 & 0.1987 & 0.2594 & 0.0203 & 0.0754 & 1 & \\
SIZE & 0.1958 & 0.0889 & 0.0661 & 0.2275 & 0.0355 & 0.0657 & 0.1716 & 1 \\
\hline
\end{tabular}

\section{The results, discussion and conclusion}

In this section, we present details of the implementation of regression technique on Eq. (1). Table 5 presents the summary of our findings.

\section{Table 5}

The summary of regression test

\begin{tabular}{ccccc}
\hline Variable & Symbol & Coefficient & t-value & Sig. \\
\hline Intercept & $\beta_{0}$ & 0.412 & 1.231 & 0.208 \\
\hline BR $_{\mathrm{jt}}$ & $\beta_{1}$ & -0.443 & -3.111 & 0.028 \\
$\mathrm{CFR}_{\mathrm{jt}}$ & $\beta_{2}$ & -0.322 & -2.909 & 0.031 \\
$\mathrm{FR}_{\mathrm{jt}}$ & $\beta_{3}$ & -0.199 & -2.291 & 0.016 \\
$\mathrm{SR}_{\mathrm{jt}}$ & $\beta_{4}$ & -0.277 & -2.129 & 0.041 \\
$\mathrm{D}_{1} \times \mathrm{BR}_{\mathrm{jt}}$ & $\beta_{5}$ & -0.309 & -3.273 & 0.0027 \\
$\mathrm{D}_{1} \times \mathrm{CFR}_{\mathrm{jt}}$ & $\beta_{6}$ & -0.188 & -3.154 & 0.002 \\
$\mathrm{D}_{1} \times \mathrm{FR}_{\mathrm{jt}}$ & $\beta_{7}$ & -0.367 & -2.381 & 0.018 \\
$\mathrm{D}_{1} \times \mathrm{SR}_{\mathrm{jt}}$ & $\beta_{8}$ & -0.252 & 2.619 & 0.009 \\
$\mathrm{D}_{2} \times \mathrm{BR}_{\mathrm{jt}}$ & $\beta_{9}$ & -0.487 & -3.073 & 0.013 \\
$\mathrm{D}_{2} \times \mathrm{CFR}_{\mathrm{jt}}$ & $\beta_{10}$ & -0.192 & -3.838 & 0.0017 \\
$\mathrm{D}_{2} \times \mathrm{FR}_{\mathrm{jt}}$ & $\beta_{11}$ & -0.386 & -2.388 & 0.041 \\
$\mathrm{D}_{2} \times \mathrm{SR}_{\mathrm{jt}}$ & $\beta_{12}$ & -0.306 & -2.141 & 0.048 \\
$\mathrm{EPS}_{\mathrm{jt}}$ & $\beta_{13}$ & 0.619 & 2.601 & 0.031 \\
$\mathrm{DIV}_{\mathrm{jt}}$ & $\beta_{14}$ & 0.583 & 2.671 & 0.025 \\
$\mathrm{SIZE}_{\mathrm{jt}}$ & $\beta_{15}$ & 0.967 & 2.576 & 0.041 \\
\hline
\end{tabular}

Adjusted R-Square $=0.418 \mathrm{~F}$-Value $=13.675$ P-value $=0.0015$

As we can observe from the results of Table 5, adjusted R-Square is equal to 0.418, which means the independent variables represent approximately $42 \%$ of the changes on dependent variable. In addition, $\mathrm{F}$ value is statistically significant, which means the regression equation represent logical relationship between independent and dependent variables. However, among t-student values, only some of them were significant. Table 6 demonstrates the results of regression coefficients before/after disclosure policy. The study shows that there was a meaningful relationship between two risks, business risk and systematic 
risk, and market value before and after corporate disclosure. In other words, after corporate disclosure, the relationship between risk and market value becomes stronger.

\section{Table 6}

The summary of the regression analysis before and after disclosure policy

\begin{tabular}{cccccc}
\hline Variable & \multicolumn{2}{c}{ Before disclosure } & \multicolumn{3}{c}{ After disclosure } \\
\hline BR & $\beta_{5}$ & -0.309 & $\beta_{9}$ & -0.487 & $2.383(0.047)$ \\
CR & $\beta_{6}$ & -0.188 & $\beta_{10}$ & -0.192 & $1.277(0.308)$ \\
FR & $\beta_{7}$ & -0.367 & $\beta_{11}$ & -0.386 & $1.521(0.153)$ \\
SR & $\beta_{8}$ & -0.252 & $\beta_{12}$ & -0.306 & $2.843(0.026)$ \\
\hline
\end{tabular}

In our study, we did not find any evidence to believe the existence of any possible relationship between firm value on one side and financial as well as cash flow risks on the other side.

\section{Acknowledgement}

The authors would like to thank the anonymous referees for constructive comments on earlier version of this paper.

\section{References}

Abraham, S., \& Shrives, P. J. (2014). Improving the relevance of risk factor disclosure in corporate annual reports. The British Accounting Review, 46(1), 91-107.

Anandarajan, A., \& Hasan, I. (2010). Value relevance of earnings: Evidence from Middle Eastern and North African countries. Advances in Accounting,26(2), 270-279.

Bertomeu, J., \& Cheynel, E. (2014). Disclosure and the Cost of Capital: A Survey of the Theoretical Literature. Columbia Business School Research Paper, (14-49).

Chung, K. H., Elder, J., \& Kim, J. C. (2010). Corporate governance and liquidity. Journal of Financial and Quantitative Analysis, 45(2), 265-291.

Ezat, A., \& El-Masry, A. (2008). The impact of corporate governance on the timeliness of corporate internet reporting by Egyptian listed companies. Managerial Finance, 34(12), 848-867.

Francis, J., Olsson, P., \& Oswald, D. R. (2000). Comparing the accuracy and explainability of dividend, free cash flow, and abnormal earnings equity value estimates (Digest Summary). Journal of accounting research, 38(1), 45-70.

Ferguson, M. J., Lam, K. C., \& Lee, G. M. (2002). Voluntary disclosure by state-owned enterprises listed on the stock exchange of Hong Kong. Journal of International Financial Management \& Accounting, 13(2), 125-152.

Gelb, D. S., \& Zarowin, P. (2002). Corporate disclosure policy and the informativeness of stock prices. Review of Accounting Studies, 7(1), 33-52.

Hasan, T., Karim, W., \& Quayes, S. (2008). Regulatory change and the quality of compliance to mandatory disclosure requirements: Evidence from Bangladesh. Research in Accounting Regulation, 20, 193-203.

$\mathrm{Li}, \mathrm{X}$. (2010). The impacts of product market competition on the quantity and quality of voluntary disclosures. Review of Accounting Studies, 15(3), 663-711.

Li, W. X., Chen, C. C. S., \& French, J. J. (2012). The relationship between liquidity, corporate governance, and firm valuation: Evidence from Russia. Emerging Markets Review, 13(4), 465-477.

Lin, H., Wang, J., \& Wu, C. (2011). Liquidity risk and expected corporate bond returns. Journal of Financial Economics, 99(3), 628-650.

Ng, J. (2011). The effect of information quality on liquidity risk. Journal of Accounting and Economics, 52(2), 126-143.

Pastor, L., \& Stambaugh, R. F. (2001). Liquidity risk and expected stock returns (No. w8462). National Bureau of Economic Research. 
Pesaran, H. H., \& Shin, Y. (1998). Generalized impulse response analysis in linear multivariate models. Economics letters, 58(1), 17-29.

Roe, M. J. (1996). Strong managers, weak owners: The political roots of American corporate finance. Princeton University Press.

Scott, W. R. (1997). Financial accounting theory (Vol. 3, pp. 335-360). Upper Saddle River, NJ: Prentice Hall.

Steger, U., \& Amann, W. (2008). Corporate governance: how to add value. John Wiley \& Sons. 